\title{
Short-Term Presynaptic Plasticity
}

\author{
Wade G. Regehr \\ Department of Neurobiology, Harvard Medical School, Boston, Massachusetts 02115 \\ Correspondence: wade_regehr@hms.harvard.edu
}

Different types of synapses are specialized to interpret spike trains in their own way by virtue of the complement of short-term synaptic plasticity mechanisms they possess. Numerous types of short-term, use-dependent synaptic plasticity regulate neurotransmitter release. Short-term depression is prominent after a single conditioning stimulus and recovers in seconds. Sustained presynaptic activation can result in more profound depression that recovers more slowly. An enhancement of release known as facilitation is prominent after single conditioning stimuli and lasts for hundreds of milliseconds. Finally, tetanic activation can enhance synaptic strength for tens of seconds to minutes through processes known as augmentation and posttetantic potentiation. Progress in clarifying the properties, mechanisms, and functional roles of these forms of short-term plasticity is reviewed here.

U se-dependent presynaptic plasticity lasting tens of milliseconds to minutes can be divided into three major categories: (1) depression, (2) facilitation, and (3) augmentation/ posttetanic potentiation (PTP). At synapses where depression is prominent, the second of two closely spaced stimuli evokes a response that is much smaller than that evoked by the first, and this reduction in synaptic strength lasts hundreds of milliseconds to seconds (Fig. 1A). Sustained stimulation produces longer-lasting depression that recovers slowly (tens of seconds to minutes; Fig. 1B). At some synapses facilitation is observed, and the second of two closely spaced stimuli evokes a larger response than the first, provided the stimuli are delivered within hundreds of milliseconds to seconds of each other
(Fig. 1C). Sustained presynaptic activation at high frequency leads to synaptic enhancement known as augmentation and PTP that lasts tens of seconds to several minutes (Fig. 1D). For these forms of plasticity each stimulus in the conditioning train produces a small amount of enhancement, but the cumulative effects of many stimuli can lead to a severalfold enhancement. I will review the properties of these classes of usedependent, short-term plasticity; discuss advances in understanding the mechanisms that mediate them; and present examples that illustrate some of their functional roles. Transient synaptic modulation mediated by activation of presynaptic G-protein-coupled receptors, although a widespread and important means of synaptic regulation, is beyond the scope of this review.

Editors: Morgan Sheng, Bernardo Sabatini, and Thomas C. Südhof

Additional Perspectives on The Synapse available at www.cshperspectives.org

Copyright (C) 2012 Cold Spring Harbor Laboratory Press; all rights reserved; doi: 10.1101/cshperspect.a005702

Cite this article as Cold Spring Harb Perspect Biol 2012;4:a005702 
W.G. Regehr

A Short-lived depression

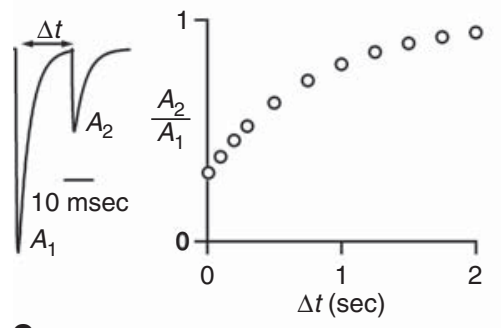

C Facilitation

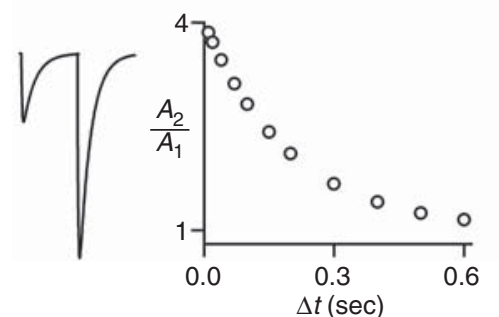

B Long-lived depression

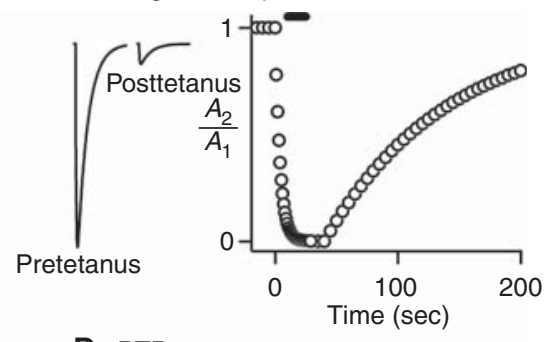

D PTP

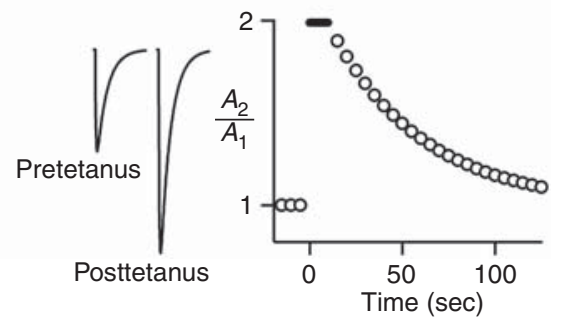

Figure 1. Forms of short-term, use-dependent plasticity. Simulated experiments show the properties of various forms of short-term plasticity. (A) Short-lived depression is observed at some synapses when the presynaptic axon is stimulated twice with a time between stimuli of $\Delta t$. (B) At some synapses low-frequency stimulation results in stable synaptic response, but sustained high-frequency stimulation results in a depression that persists for tens of seconds even when low-frequency stimulation is resumed. (C) Paired-pulse facilitation that lasts for hundreds of milliseconds is observed at some synapses. (D) Augmentation or posttetanic potentiation of synaptic responses lasting tens of seconds or minutes after tetanic stimulation is observed at some synapses.

\section{IMPORTANT FACTORS RELEVANT TO SHORT-TERM PLASTICITY}

\section{Presynaptic Calcium Signaling}

Calcium plays a prominent role in many usedependent forms of plasticity (Burnashev and Rozov 2005; Neher and Sakaba 2008; de Jong and Verhage 2009). When an action potential invades a presynaptic terminal, it opens voltagegated calcium channels. Vesicle fusion is triggered by high local calcium concentrations $\left(\mathrm{Ca}_{\text {local }}, 10-100 \mu \mathrm{M}\right)$ at release sites near open calcium channels (Schneggenburger and Neher 2005). The magnitude of synaptic strength is steeply dependent upon calcium levels, because calcium binds to multiple low-affinity sites on synaptotagmin to trigger vesicle fusion (Jahn et al. 2003; Schneggenburger and Neher 2005;

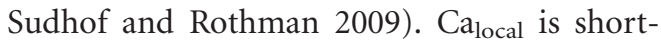
lived, is highly sensitive to the distance between open calcium channels and the release site, and can be affected by calcium-binding proteins in the presynaptic bouton (Roberts 1993; Neher
1998; Matveev et al. 2004). Calcium-binding proteins with rapid kinetics are particularly effective at intercepting calcium before it can reach release sites, thereby reducing the probability of release (Roberts 1993). After calcium channels close, spatial gradients collapse as calcium diffuses and binds to calcium-binding proteins within the presynaptic bouton (Fogelson and Zucker 1985; Simon and Llinas 1985). The remaining calcium, known as residual calcium $\left(\mathrm{Ca}_{\mathrm{res}}\right)$, is then gradually extruded from the presynaptic bouton (Neher and Augustine 1992; Tank et al. 1995). $\mathrm{Ca}_{\text {res }}$ levels are much lower (hundreds of nanomolar) and longerlived (hundreds of milliseconds to seconds) than those of $\mathrm{Ca}_{\text {local }}$, and play an important role in short-term plasticity.

\section{Vesicle Pools}

The properties of the vesicles within a presynaptic terminal are another important determinant of synaptic efficacy and are factors in 
short-term plasticity (Fig. 2A). It has been convenient to categorize vesicles into different functional pools (Schneggenburger et al. 2002; Rizzoli and Betz 2005; Becherer and Rettig 2006; Schweizer and Ryan 2006). However, there are no universally accepted definitions for these different vesicle pools, and they are referred to by different nomenclatures. Here I will adopt the terminology used by Betz (Rizzoli and Betz 2005). There are usually hundreds of vesicles associated with each active zone. A fraction of these vesicles (typically 10\%-20\%) constitute the recycling pool (RP) that is released with sustained high-frequency activation. It is difficult to evoke the release of the remaining pool of vesicles, known as the nonrecycling pool (NRP). The readily releasable pool (RRP) is immediately available when the presynaptic cell is stimulated. The size of the RRP can be determined by applying an extracellular solution of hypertonic sucrose (Rosenmund and Stevens 1996), assuming that the osmotic shock and the action potential-dependent calcium influx target the same pool of vesicles, or by using a large sustained elevation of presynaptic calcium produced by either depolarizing the presynaptic

A
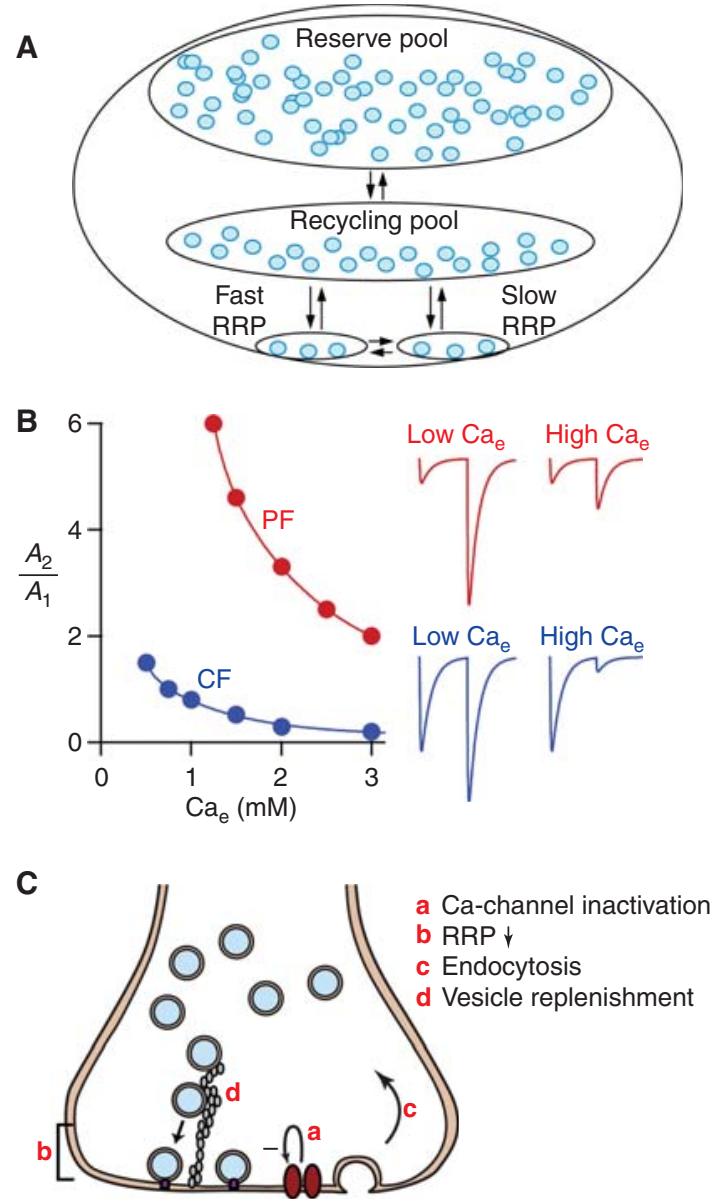

Figure 2. Factors relevant to depression. (A) Different pools of vesicles in a presynaptic bouton. For simplicity the pools are depicted as being clustered together and at different distances from the active zone. It is clear that at least in some cases the pools intermingle, indicating that spatial location within the bouton is insufficient to account for the different properties of synaptic vesicles. $(B)$ The dependence of paired-pulse plasticity on initial release probability. $(C)$ Schematic showing mechanisms of synaptic depression. Abbreviations: PF, parallel fiber; $\mathrm{CF}$, climbing fiber. 
W.G. Regehr

terminal or uncaging calcium (Schneggenburger et al. 2002; Rizzoli and Betz 2005; Fioravante and Regehr 2011). The RRP typically consists of several percent of the vesicles within a presynaptic bouton (Rizzoli and Betz 2005; Becherer and Rettig 2006; Schweizer and Ryan 2006). At some synapses the RRP can be divided into fast and slow vesicle pools, which are differentially recruited and which differ in their propensity to release (Wu and Borst 1999; Sakaba and Neher 2001). The different pools of vesicles may reflect vesicles near to (fast vesicles) and far from (slow vesicles) voltage-gated calcium channels (Wadel et al. 2007). Another commonly used approach to determine the size of the RRP is to stimulate the synapse with a high-frequency train of action potentials $\left(\mathrm{RRP}_{\text {train }}\right)$, which typically yields a lower estimate of RRP than that obtained by other methods (Schneggenburger et al. 2002; Fioravante and Regehr 2011). Measurements of RRP are often used to clarify the mechanisms of short-term plasticity, but their utility is limited by uncertainty regarding the interpretation of the RRP, the fast and slow components of the $\mathrm{RRP}$, and $\mathrm{RRP}_{\text {train. }}$.

\section{Postsynaptic Factors}

Postsynaptic mechanisms can also mediate short-term plasticity, and they can complicate the characterization of presynaptic mechanisms. For example, saturation of postsynaptic receptors can limit responses, particularly when the probability of release is high (Wadiche and Jahr 2001; Foster et al. 2002). As a result, synaptic currents can underestimate the extent to which presynaptic mechanisms facilitate or depress transmitter release at some synapses. Low-affinity AMPA receptor antagonists, such as $\gamma$-D-glutamylglycine or kynurenate, can minimize the extent of saturation of these receptors (Neher and Sakaba 2001; Wadiche and Jahr 2001). Postsynaptic receptors can also desensitize, making them unavailable for subsequent activation, and leading to short-term decreases in synaptic responses (Trussell et al. 1993; Chen et al. 2002; Xu-Friedman and Regehr 2004). It is possible to prevent AMPA receptor desensitization pharmacologically (Francotte et al. 2006), but it may not be possible to prevent desensitization of other types of receptors. Thus, at glutamatergic synapses presynaptic mechanisms can be studied with minimal interference from saturation and desensitization of postsynaptic receptors, but this may not be the case at nonglutamatergic synapses.

\section{Multiple Forms of Plasticity Coexist at the Same Synapse}

Most synapses possess multiple forms of presynaptic plasticity, and net synaptic strength reflects an interaction between these forms of plasticity (Dittman et al. 2000; Zucker and Regehr 2002; Pan and Zucker 2009). Often, shortterm depression, facilitation, PTP, and longerlasting depression are all present, but the relative prominence of each of the mechanisms is controlled by the initial release probability and the presynaptic activity pattern. This is apparent in the plasticity induced by two closely spaced stimuli. The extent of paired-pulse plasticity depends on the initial probability of release, and synapses with a high initial probability of release tend to depress, whereas those with a low initial probability of release usually facilitate. Indeed, most synapses can show either facilitation or depression depending on the initial probability of release. This is illustrated by altering the extracellular calcium $\left(\mathrm{Ca}_{\mathrm{e}}\right)$ to change the initial probability of release. At the climbing fiber-to-Purkinje cell synapse in the cerebellum, depression is prominent when the release probability is high (in high $\mathrm{Ca}_{\mathrm{e}}$ ), but paired-pulse facilitation is observed when the release probability is low (in low $\mathrm{Ca}_{\mathrm{e}}$ ) (Fig. 2B, blue trace) (Foster et al. 2002). Classic model synapses, such as the squid giant synapse and the calyx of Held, behave similarly (Charlton and Bittner 1978; von Gersdorff and Borst 2002). For granule cell-to-Purkinje cell synapses, facilitation is sixfold in low $\mathrm{Ca}_{\mathrm{e}}$ and much smaller in high $\mathrm{Ca}_{\mathrm{e}}$ (Fig. 2B, red trace) (Foster et al. 2005). At synapses with such a low probability of release it can be exceedingly difficult to observe paired-pulse depression. This may be because it is difficult to elevate the probability of release sufficiently or because these 
synapses possess molecular specializations that limit depression (Hallermann et al. 2010).

\section{DEPRESSION}

\section{The Depletion Model of Depression}

Many aspects of paired-pulse depression are readily explained by the depletion model of depression (Liley and North 1953; Betz 1970; Zucker and Regehr 2002). According to the simplest form of this model, the first stimulus triggers the release of a large fraction $F$ of the RRP. If there are $S$ releasable vesicles in the RRP and each vesicle produces a current $i$ in the postsynaptic cell, then the initial excitatory postsynaptic current (EPSC) has an amplitude $A_{1}=F S i$. If the released vesicles are not immediately replaced, then the RRP is depleted and only $S-$ $F S$ vesicles are available for release by the second stimulus. If the probability of evoking the fusion of each of the remaining vesicles remains unchanged, then the amplitude of the second EPSC is $A_{2}=S(1-F) F i$, and paired-pulse plasticity is $A_{2} / A_{1}=(1-F)$. If depression is to occur in accordance with the depletion model, then the fraction of the RRP released by the initial stimulus must be large, and replenishment from the RRP must be slow.

The extent of depletion depends crucially on the number of vesicles in the RRP at each active zone and the number of vesicles released by an action potential. Serial electron microcopy has also been used to determine the number of morphologically docked vesicles, which may correspond to the RRP. However, some of the docked vesicles may not be primed, and the RRP need not be restricted to docked vesicles. The average number of morphologically docked vesicles at the active zone of different synapses ranges from two vesicles at the calyx of Held (Satzler et al. 2002) to 27 for inputs onto pyramidal cells in the pyriform cortex (Schikorski and Stevens 1999). For most types of synapses a single stimulus would only result in substantial depletion if it triggered the fusion of multiple vesicles. Although a prominent theory maintained that an action potential could evoke the release of at most a single vesicle at individual active zones (Redman 1990; Korn et al. 1994), multiple lines of evidence have established that at many synapses multivesicular release occurs (Wadiche and Jahr 2001; Xu-Friedman and Regehr 2004).

The depletion model accounts for the basic properties of paired-pulse depression observed at many synapses. Most importantly, the larger the initial probability of release, the greater the depletion of vesicles and the more pronounced the paired-pulse depression (Fig. 2B). According to the depletion model, if more vesicles fuse in response to the initial stimulus, there is more depletion of the RRP and fewer vesicles are released by the second stimulus. Thus, the depletion model predicts a negative correlation between EPSC2 and EPSC1 for two closely spaced stimuli. Consistent with this prediction, a negative correlation between the amplitudes of two closely spaced EPSCs has been observed at the neuromuscular junction (Elmqvist and Quastel 1965), hair cell synapses (Furukawa et al. 1978), the calyx of Held (Scheuss et al. 2002), thalamocortical synapses (Ran et al. 2009), cortical connections (Thomson et al. 1993), and hippocampal synapses (Debanne et al. 1996). However, at some synapses the extent of depression does not appear to depend on the magnitude of release evoked by the first stimulus (Thomson and Bannister 1999; Kraushaar and Jonas 2000; Chen et al. 2004) or the size of the RRP (Sullivan 2007), and an inverse correlation has not been seen at synapses onto Mauthner cells (Waldeck et al. 2000) and at hippocampal synapses (Chen et al. 2004). Thus, a simple depletion model cannot account for the properties of depression at many synapses.

\section{Inactivation of Release Sites}

According to a second model of synaptic depression, fusion of a vesicle at an active zone can inhibit subsequent fusion of available vesicles for several seconds (Betz 1970; Kusano and Landau 1975; Varela et al. 1997; Dittman and Regehr 1998; Neher and Sakaba 2008). Impaired vesicle fusion could reflect the time it takes to clear vesicular membrane proteins from near the active zone following vesicle fusion. A recent 
W.G. Regehr

study found that blocking endocytosis leads to more pronounced depression during trains (Hosoi et al. 2009). These findings suggest that endocytosis clears vesicular membrane proteins from the plasma membrane, where they interfere with release, thereby allowing sites to recover from inactivation more rapidly than if these proteins were removed by diffusion within the membrane. Site inactivation does not appear to occur at many types of synapses, which are capable of releasing tens of vesicles per active zone each second (Saviane and Silver 2006; Crowley et al. 2007).

\section{Depression following Tetanic Stimulation}

At most synapses sustained high-frequency activation eventually results in profound depression, and recovery from this depression is much slower (many tens of seconds) than for pairedpulse depression (seconds) (Eccles and O'Connor 1941; Feng 1941; del Castillo and Katz 1954; Betz 1970; Thomson et al. 1993). Such depression has been explained in terms of depleting the RP. In this case the stimulation would have to be sufficiently prolonged to deplete the RP, and sufficiently high frequency such that replenishment from the NRP or recycling via endocytosis would be unable to keep up with vesicle loss during tetanic stimulation. Following sustained stimulation the time constant of recovery shifts from seconds to tens of seconds. This may reflect a slowing of the replenishment of the RRP from the recycling pool (Stevens and Wesseling 1999), decreases in calcium entry (Catterall and Few 2008), or a decrease in the probability of release.

\section{Inactivation of Calcium Channels and Other Mechanisms of Depression}

Several factors could contribute to the use-dependent decrease of synaptic transmission in cases that do not conform to predictions from the depletion model. An alteration in the firing threshold for somatic or extracellular activation that involves the $\mathrm{Na} / \mathrm{K}$-ATPase could contribute to short-term depression at these synapses (Munoz-Cuevas et al. 2004). A failure of an ac- tion potential to invade some axonal branches may contribute to depression in cultured hippocampal cells (Brody and Yue 2000; Prakriya and Mennerick 2000), but action potential invasion of axons is generally reliable in more intact tissue (Cox et al. 2000; Kreitzer and Regehr 2001; Brenowitz and Regehr 2007).

There is particularly compelling evidence that use-dependent decreases in presynaptic calcium entry can make important contributions to depression (Catterall and Few 2008). Multiple calcium-sensing proteins, including calmodulin, calcium-binding protein-1, and visinin-like protein-2, can interact with calcium channels and mediate use-dependent changes in presynaptic calcium entry (Lee et al. 1999, 2002; Peterson et al. 1999; Lautermilch et al. 2005). Presynaptic recordings from the calyx of Held have shown that prolonged high-frequency stimulation reduces calcium entry (Forsythe et al. 1998) that can contribute to depression. Remarkably, small numbers of stimuli at low frequency can reduce calcium entry sufficiently that it can substantially reduce synaptic transmission (Xu and $\mathrm{Wu} 2005$ ). At the calyx of Held synapse, short-term depression is largely a result of decreased calcium entry for activation frequencies of $<30 \mathrm{~Hz}$ and primarily a result of depletion at frequencies $>100 \mathrm{~Hz}$; at intermediate frequencies both mechanisms contribute (Xu and Wu 2005). Studies of synaptic transmission in cultured superior cervical ganglion neurons expressing calcium channels that either possess or lack calmodulin-dependent inactivation suggest that depression can arise from calcium channel inactivation mediated by calmodulin (Mochida et al. 2008).

\section{Calcium-Dependent Recovery from Depression}

According to the depletion model, recovery from depression occurs when the RRP is replenished by vesicles from the recycling pool. Paired-pulse depression typically recovers with a time constant of several seconds. However, elevations of presynaptic calcium can greatly accelerate recovery from depression (Dittman and Regehr 1998; Stevens and Wesseling 1998, 
1999; Wang and Kaczmarek 1998; Sakaba 2008; Yang and Xu-Friedman 2008), presumably by accelerating replenishment of the RRP. This acceleration is prevented by inhibiting calmodulin (Sakaba and Neher 2001; Hosoi et al. 2007), but the downstream target of calmodulin remains unclear. Munc13 is a potential target of calmodulin that is involved in priming vesicles (Augustin et al. 1999). Replenishment of release-ready vesicles is approximately linearly related to presynaptic calcium levels, and during high-frequency stimulus trains calcium can accelerate vesicle recruitment by a factor of 10 (Hosoi et al. 2007).

The mechanisms that contribute to synaptic depression are summarized in Figure 2C.

Regulation of Depression and Recovery from Depression

Some synapses have molecular specializations that control the extent of depression. For example, the knockout of Bassoon, a large presynaptic protein present at the active zone, leads to enhanced synaptic depression, suggesting that Bassoon normally minimizes depression by helping to rapidly replenish vesicles at release sites (Hallermann et al. 2010). Conversely, at the calyx of Held synapse, activation of $\mathrm{G}_{\mathrm{i} / \mathrm{o}^{-}}$ coupled receptors lowers presynaptic cAMP, which prevents calcium-dependent recovery from depression (Sakaba and Neher 2003).

Several proteins have been implicated in regulating recovery from depression. These include $\alpha$-synuclein, a protein best known for its involvement in Parkinson's disease. The elimination of $\alpha$-synuclein reduces the size of the pool of nondocked vesicles by $\sim 40 \%$ and reduces the extent of depression during sustained stimulation by $\sim 30 \%$ (Cabin et al. 2002). Conversely, the elimination of rabphilin - a protein that interacts with the GTP-binding proteins Rab3A to $-\mathrm{D}$, contains two C2 domains that bind calcium, and binds to the SNARE protein SNAP-25-accelerates recovery from depression following $20-\mathrm{Hz}, 60-\mathrm{sec}$ stimulation (fast component of recovery with $\tau=4$ sec becomes prominent, whereas slow component with $\tau=$ $60 \mathrm{sec}$ dominates in control conditions [Deak et al. 2006]). The elimination of synapsins decreases the number of vesicles in presynaptic boutons and leads to more pronounced depression during sustained moderate-frequency stimulation (Rosahl et al. 1995; Gitler et al 2008). Thus, there is a growing list of molecules implicated in recovery from depression, and at present the mechanism by which these molecules regulate recovery from depression is not known.

\section{FACILITATION}

A simple form of the residual calcium hypothesis was advanced long ago to account for facilitation (Katz and Miledi 1968). According to this hypothesis, the initial presynaptic action potential evokes a local calcium signal that triggers release, but then calcium persists at a lower level in the presynaptic bouton. If the amplitude of the initial EPSC is $A_{1}=k\left(\mathrm{Ca}_{\text {local }}\right)^{4}$, then the amplitude of the second EPSC would be $A_{2}=$ $k\left(\mathrm{Ca}_{\text {res }}+\mathrm{Ca}_{\text {local }}\right)^{4}$ (where $k$ is a constant). This would result in facilitation if the residual calcium signal is a significant fraction of the local calcium signal that drives release (Fig. 3A, red trace). For example, $\mathrm{Ca}_{\text {res }} / \mathrm{Ca}_{\text {local }}=0.16$ would result in twofold facilitation. Although $\mathrm{Ca}_{\text {res }} /$ $\mathrm{Ca}_{\text {local }}$ is not known for most synapses, $\mathrm{Ca}_{\text {local }}$ is estimated to be $\sim 25 \mu \mathrm{M}$ (Schneggenburger and Neher 2005), and $\mathrm{Ca}_{\text {res }}$ is $\sim 1 \%$ of $\mathrm{Ca}_{\text {local }}$. According to these estimates, only an $\sim 4 \%$ enhancement would arise from residual calcium (Fig. 3A, blue trace). This suggests that for most synapses this model fails to account for pairedpulse facilitation.

A second possibility is that calcium produces facilitation by acting at a presynaptic calcium sensor distinct from synaptotagmin (Fig. 3B) (Stanley 1984; Bain and Quastel 1992; Yamada and Zucker 1992; Atluri and Regehr 1996; Bertram et al. 1996). Synaptotagmin binds calcium rapidly with low affinity, and is therefore well suited to responding quickly to a brief high calcium signal to rapidly evoke vesicle fusion (Fig. 3B, blue trace). In contrast, a high-affinity calcium-binding site with slow kinetics might respond somewhat slowly to calcium and might be quite sensitive to the residual calcium signal 
W.G. Regehr
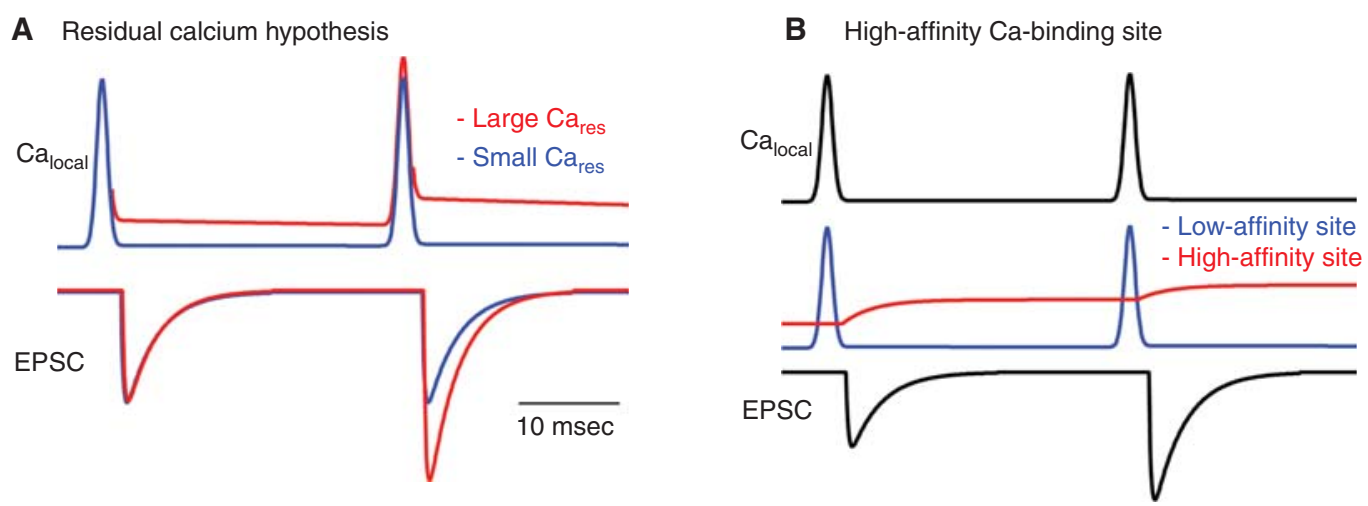

C Calcium buffer saturation

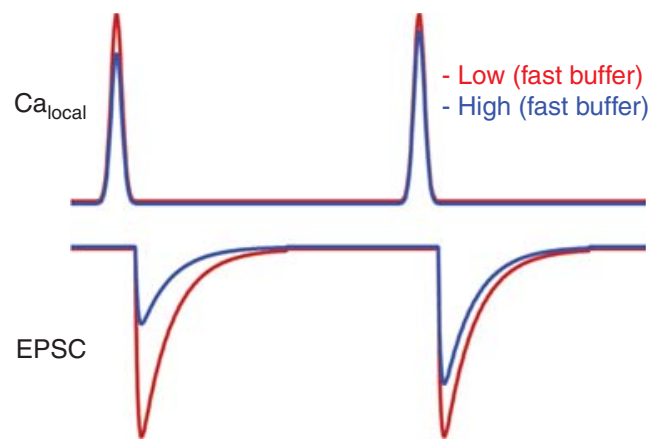

D Slow calcium buffer

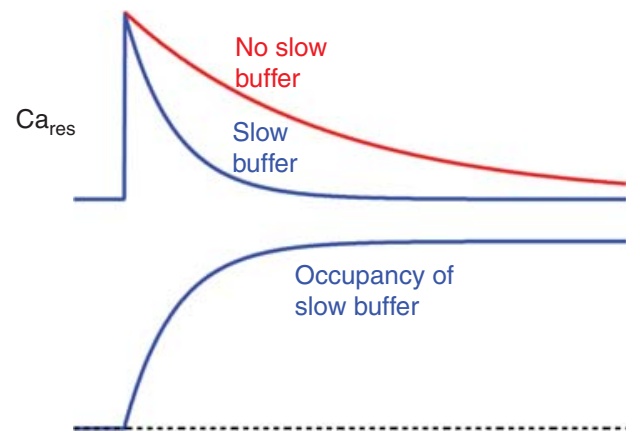

E Mechanisms of synaptic facilitation

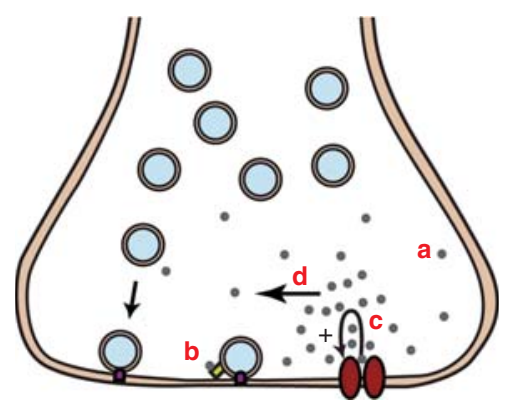

a $\mathrm{Ca}_{\text {res }}$

b Ca $a_{\text {res }}$ sensor

c Ca-channel facilitation

dBuffer saturation

Figure 3. Proposed mechanisms of facilitation. (A) The residual calcium hypothesis based on a single type of low-affinity calcium sensor is shown for two types of calcium signals. When the residual calcium signal is a significant fraction of the local calcium signal, significant facilitation occurs (red traces), but when the residual calcium signal is much smaller than the calcium signal near the calcium channel, this mechanism results in very little enhancement (blue traces). (B) Another type of residual calcium model is shown that is based on two types of calcium sensors, a fast, low-affinity sensor and a slow, high-affinity sensor. The residual calcium signal can activate the high-affinity receptor to produce facilitation. $(C)$ A comparison of the calcium signals and resulting EPSCs for a synapse in which a presynaptic bouton contains either a high concentration (blue) or a low concentration (red) of a rapid calcium buffer illustrates another mechanism of facilitation. $(D)$ A slow calcium buffer binds presynaptic calcium slowly and by doing so accelerates the decay of presynaptic calcium, which can in turn affect facilitation. (E) Schematic illustrating mechanisms of facilitation. 
(Fig. 3B, red trace). The time course of calcium activation of this receptor could track the $\mathrm{Ca}_{\text {res }}$ signal in the presynaptic terminal, or it could outlive $\mathrm{Ca}_{\text {res }}$ if the kinetics of calcium binding to the receptor are slow.

The presence of high-affinity calcium buffers in presynaptic boutons can also produce facilitation. If present at sufficiently high concentrations, they can bind calcium after it enters through voltage-gated calcium channels and before it reaches release sites (Adler et al. 1991; Roberts 1993; Neher 1998). In this way calciumbinding proteins can reduce $\mathrm{Ca}_{\text {local }}$ at the release site. Fast calcium buffers such as calbindin can reduce the initial probability of release in the same way that introducing the fast buffer BAPTA into the presynaptic terminal lowers the initial probability of release. If calcium levels in the presynaptic bouton are sufficiently high, then after the first stimulus a high-affinity calciumbinding protein will be primarily bound to calcium. As a result, more of the calcium that enters the bouton in response to a subsequent action potential will reach the release site. In this way local buffer saturation can contribute to pairedpulse plasticity (Neher 1998; Rozov et al. 2001; Blatow et al. 2003; Felmy et al. 2003; Matveev et al. 2004). This is illustrated by comparing the effects of calcium-binding proteins on presynaptic calcium signals, EPSCs, and facilitation when there is a high concentration of a fast buffer (Fig. 3C, blue trace) and a low concentration of fast buffer (Fig. 3C, red trace).

Slow calcium-binding proteins can also influence facilitation, but in a very different way than fast calcium-binding proteins. Some endogenous buffers act much like the slow buffer EGTA (Atluri and Regehr 1996). For example, parvalbumin binds calcium so slowly that it does not affect peak calcium levels, and therefore has little effect on the initial probability of release. As parvalbumin slowly binds calcium, it accelerates the decay of residual calcium in the presynaptic bouton (Caillard et al. 2000; Lee et al. 2000; Muller et al. 2007), as is shown in Figure 3D. By controlling the speed of calcium decay, parvalbumin regulates paired-pulse plasticity and the time course of facilitation (Caillard et al. 2000; Muller et al. 2007).
Use-dependent facilitation of calcium entry can increase the probability of release and contribute to facilitation. Calcium currents can be enhanced in a use-dependent manner when calcium activates calcium-sensitive proteins such as calmodulin to modulate voltage-gated calcium channels (Inchauspe et al. 2004; Ishikawa et al. 2005; Catterall and Few 2008). At synapses between cultured superior cervical ganglion neurons, mutating P-type calcium channels to prevent calcium-dependent facilitation of calcium currents strongly attenuates synaptic facilitation (Mochida et al. 2008).

Mechanisms that can contribute to synaptic facilitation are summarized in Figure 3E.

\section{POSTTETANIC POTENTIATION AND AUGMENTATION}

Posttetanic potentiation was first described more than 100 years ago when it was found that nerve stimulation that initially was unable to trigger muscle contraction became capable of triggering contractions following a period of sustained high-frequency stimulation known as tetanic potentiation (Schiff 1858; Boehm 1894; Hughes 1958). PTP initially referred to the enhanced ability of the nerve to activate the muscle, but when subsequent studies revealed that tetanic stimulation increased the amplitude of evoked synaptic responses, this increase in synaptic strength become known as PTP (Feng 1941; Hughes 1958; Magleby and Zengel 1975; Zucker and Lara-Estrella 1983; Magleby 1987; Griffith 1990; Zucker and Regehr 2002). PTP now refers to a transient increase in synaptic strength lasting tens of seconds to minutes that follows sustained high-frequency stimulation. In general, more prolonged tetanic stimulation results in longer-lasting PTP (Magleby 1987). At many synapses a closely related form of transient enhancement known as augmentation is present, which has a shorter duration than PTP; is evoked by lower-frequency, shorter-duration stimulation than PTP; and has a time course that is relatively insensitive to the duration of tetanic activation (Magleby 1987). Different synapses show considerable variability in the number and frequency of 
W.G. Regehr

stimuli needed to induce PTP and augmentation, and the distinction between augmentation and PTP is often unclear.

In addition to affecting the amplitude of evoked synaptic currents, tetanic stimulation increases the frequency of spontaneous miniature synaptic events (minis). This phenomenon was first described at the neuromuscular junction (del Castillo and Katz 1954) and has subsequently been seen at many other synapses (Magleby 1987; Delaney and Tank 1994; Eliot et al. 1994; Habets and Borst 2005; Korogod et al. 2005, 2007; He et al. 2009). The observations that the elevations in the frequency of spontaneous events and PTP have similar time courses in some cases, and that both are a consequence of increases in nerve terminal calcium, have prompted speculation that a common mechanism might produce both phenomena (Magleby 1987).

Several prominent mechanisms that have been proposed to account for PTP involve calcium. One possibility is that tetanic stimulation increases $\mathrm{Ca}_{\text {local }}$ induced by subsequent action potentials, thereby increasing the probability of neurotransmitter release. $\mathrm{Ca}_{\text {local }}$ could be elevated as a result of saturating presynaptic calcium buffers without actually altering presynaptic calcium entry, as has been proposed for facilitation. At present there is no evidence that this mechanism contributes to PTP or augmentation. If such a mechanism occurred as a result of buffering within the entire presynaptic bouton, it would result in tetanus-induced changes in presynaptic calcium that could be readily measured. However, if it involved highly localized calcium buffering in the vicinity of release sites, it would be exceedingly difficult to test experimentally. Alternatively, increases in $\mathrm{Ca}_{\text {local }}$ could arise from increased calcium influx. At the calyx of Held, tetanic stimulation that produced PTP is accompanied by an increase in action potential-evoked calcium influx (Habets and Borst 2006; Korogod et al. 2007). The increase in calcium influx and PTP had the same time course, and based on the steep calcium dependence of neurotransmitter release, this elevated calcium entry could account for a large fraction of the synaptic enhancement of PTP (Habets and Borst 2006;
Korogod et al. 2007). Increases in calcium influx could arise by altering the presynaptic waveform or by changing the response of calcium channels to the same waveform (Catterall and Few 2008). Synaptic transmission is highly sensitive to changes in presynaptic waveform (Augustine 1990; Sabatini and Regehr 1997), and tetanization has been shown to produce spike broadening and increased calcium entry at mossy fiber synapses (Geiger and Jonas 2000). However, PTP does not require presynaptic waveform changes at some synapses (Martin and Pilar 1964), and there is little direct evidence supporting a presynaptic waveform change in PTP. Activity-dependent increases in presynaptic calcium influx (independent of waveform changes) following tetanic stimulation could contribute to PTP (Cuttle et al. 1998; Inchauspe et al. 2004; Ishikawa et al. 2005; Habets and Borst 2006). However, studies of cultured superior cervical ganglion synapses suggest that facilitation of calcium entry could contribute to synaptic augmentation but not PTP (Mochida et al. 2008).

Another possibility is that tetanic stimulation elevates $\mathrm{Ca}_{\text {res}}$, which leads to an increase in the probability of release by activating calcium sensors other than synaptotagmin. At synapses including the crayfish neuromuscular junction and the calyx of Held synapse, following tetanic stimulation there is a buildup of $\mathrm{Ca}_{\text {res }}$ that returns to resting levels with a time course that is similar to that of PTP (Delaney et al. 1989; Delaney and Tank 1994; Brain and Bennett 1997; Habets and Borst 2005; Korogod et al. 2007). The linear correlation between EPSC amplitude and $\mathrm{Ca}_{\text {res }}$ is compatible with a mechanism in which an increase in $\mathrm{Ca}_{\text {res }}$ of several hundred nanomolar leads to a doubling of synaptic strength. Following tetanic stimulation at some hippocampal and cerebellar synapses, $\mathrm{Ca}_{\text {res }}$ decays more rapidly than does PTP, suggesting that $\mathrm{Ca}_{\text {res }}$ may activate a slow biochemical cascade, and the kinetics of this calciumdriven process help to determine the duration of PTP (Regehr et al. 1994; Brager et al. 2003; Beierlein et al. 2007).

For $\mathrm{Ca}_{\text {res }}$ to produce PTP, it is necessary for $\mathrm{Ca}_{\text {res }}$ to remain elevated for a prolonged period 
following tetanic stimulation, and this is indeed the case. Following tetanic stimulation presynaptic calcium typically returns to resting levels with a multiexponential decay with a slow component that has a time constant of tens of seconds to minutes (Fig. 4A) (Zucker and Regehr 2002). The properties of calcium decay following tetanic stimulation are incompatible with simple models of calcium regulation, which are better suited to describing the calcium decays following a small number of stimuli, during which calcium usually returns to resting levels in hundreds of milliseconds to seconds (Neher and Augustine 1992; Tank et al. 1995). Two mechanisms have been proposed to account for the slow decay phase. At some synapses prolonged signals following tetanic stimulation in- volve mitochondria within presynaptic boutons (Fig. 4B) (Tang and Zucker 1997; Zhong et al. 2001; Garcia-Chacon et al. 2006; Lee et al. 2007). During tetanic activation $\mathrm{Ca}_{\text {res }}$ increases are blunted as calcium enters mitochondria; when stimulation ends, the decay of $\mathrm{Ca}_{\text {res }}$ is prolonged as calcium leaves the mitochondria. Blocking calcium loading into mitochondria prevents the late phase of calcium decay and greatly reduces the magnitude of PTP boutons (Tang and Zucker 1997; Zhong et al. 2001; Lee et al. 2007). At other synapses the $\mathrm{Na} / \mathrm{Ca}$ exchanger appears to be involved in prolonging the decay of calcium (Fig. 4C) (Mulkey and Zucker 1992; Regehr 1997; Zhong et al. 2001). Following tetanic stimulation the $\mathrm{Na} /$ $\mathrm{Ca}$ exchanger and the Ca-ATPase initially work

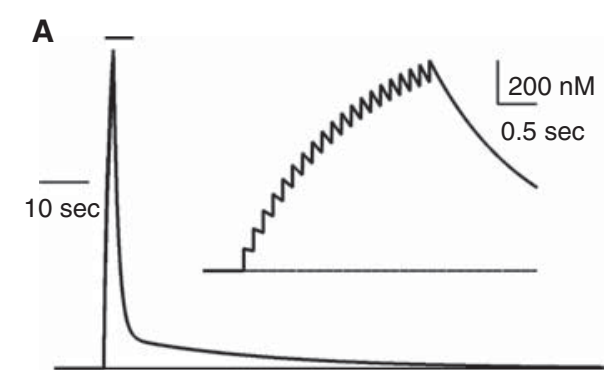

B
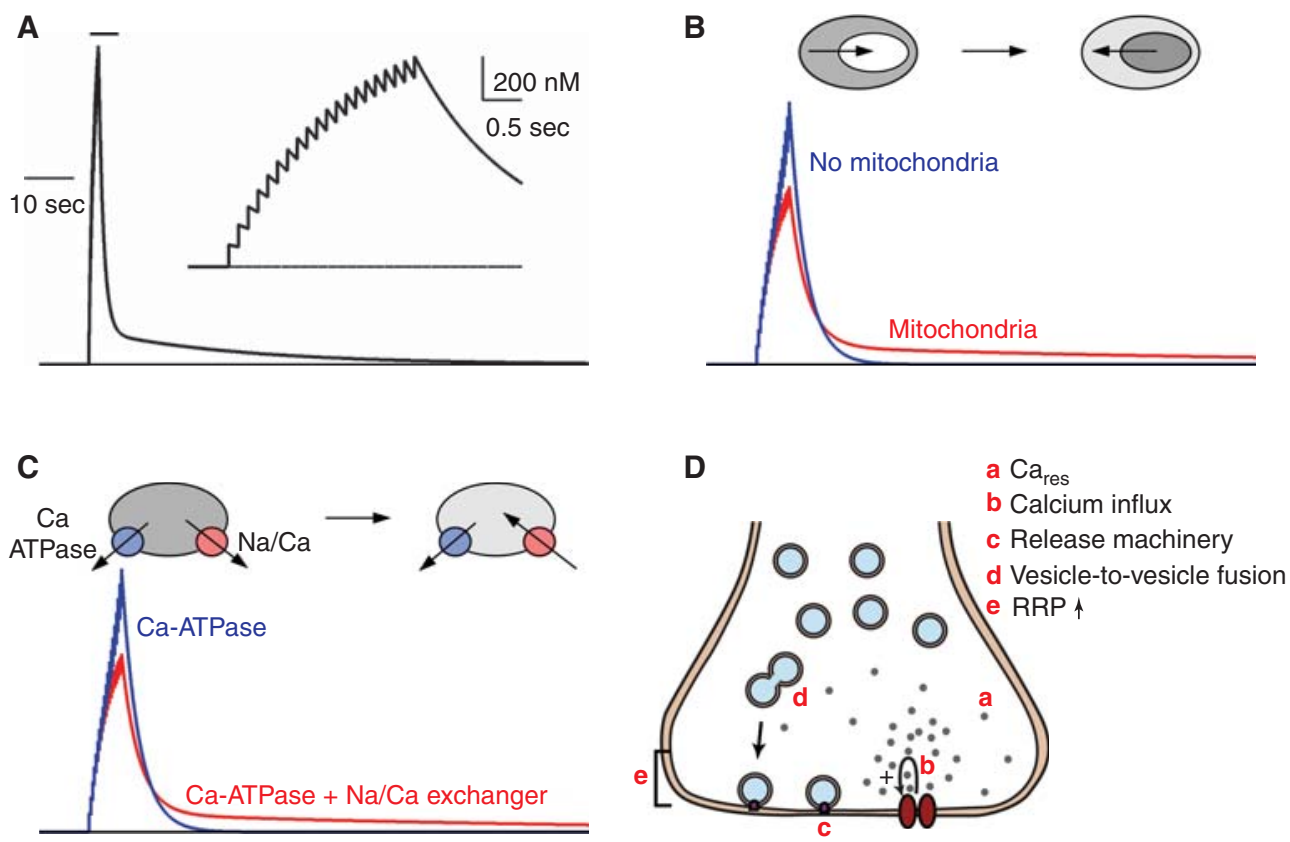

Figure 4. Proposed mechanisms of augmentation and PTP. $(A)$ The $\mathrm{Ca}_{\text {res }}$ evoked by tetanic stimulation. (Inset) The buildup of $\mathrm{Ca}_{\text {res }}$. After the stimulus $\mathrm{Ca}_{\text {res }}$ decays with a fast and slow component. Two mechanisms have been shown to account for the slow component of $\mathrm{Ca}_{\text {res }}$ decay. $(B)$ One possibility is that calcium loads the mitochondria during tetanic stimulation, and then afterwards calcium leaks out of the mitochondria and thereby leads to a sustained elevation of calcium in the presynaptic bouton. $(C)$ Another possibility is that the interplay of $\mathrm{Na} / \mathrm{Ca}$ exchanger and the Ca-ATPase leads to sustained calcium increases. During and immediately after tetanic stimulation, calcium is rapidly extruded through both the $\mathrm{Na} / \mathrm{Ca}$ exchanger and the $\mathrm{Ca}$ ATPase. At some point the $\mathrm{Na} / \mathrm{Ca}$ exchanger has removed sufficient calcium, and there is a sufficient buildup of sodium in the terminal that it reaches its reversal potential, opposes the Ca-ATPase, and leads to a very slow $\mathrm{Ca}_{\text {res }}$ decay. (D) Schematic showing mechanisms of augmentation and PTP. 
W.G. Regehr

together to remove calcium from the presynaptic bouton and calcium decays rapidly to a level that is several hundred nanomolar above resting levels (Regehr 1997). Then, because presynaptic $\mathrm{Na}$ levels are elevated, the $\mathrm{Na} / \mathrm{Ca}$ exchanger no longer removes $\mathrm{Ca}$ and the Ca-ATPase must slowly remove calcium, and $\mathrm{Ca}_{\text {res }}$ returns to resting levels only when Na returns to resting levels.

If $\mathrm{Ca}_{\text {res }}$ increases cause PTP, then altering $\mathrm{Ca}_{\text {res }}$ dynamics should modify the amplitude and time course of PTP and augmentation. This was shown to be the case at the crayfish neuromuscular junction, where slowing $\mathrm{Ca}_{\text {res }}$ decay by increasing the buffer capacity of presynaptic boutons also prolonged the duration of augmentation, while maintaining a linear relationship between $\mathrm{Ca}_{\text {res }}$ and synaptic enhancement (Delaney and Tank 1994). This suggests that at the crayfish neuromuscular junction $\mathrm{Ca}_{\text {res }}$ is responsible for the enhancement following tetanic activation.

Multiple candidate molecules have been proposed that could respond to $\mathrm{Ca}_{\text {res }}$ to produce PTP. Pharmacological studies implicated protein kinase $\mathrm{C}(\mathrm{PKC})$ in PTP at several synapses (Alle et al. 2001; Brager et al. 2003; Beierlein et al. 2007; Korogod et al. 2007). However, the involvement of PKC in PTP was uncertain because the selectivity and specificity of PKC activators and inhibitors was called into question (Brose and Rosenmund 2002; Lee et al. 2008), and PTP was unaffected by PKC inhibitors at some synapses (Reymann et al. 1988a,b; Eliot et al. 1994; Lee et al. 2008). The use of knockout animals established that calcium-dependent PKC accounts for $\sim 80 \%$ of PTP at the calyx of Held (Fioravante et al. 2011). The involvement of calcium-sensitive isoforms suggests that PKC responds to $\mathrm{Ca}_{\text {res }}$ to produce PTP, possibly by phosphorylating Munc18-1 to alter the effective pool size and the probability of release (Nili et al. 2006; Toonen et al. 2006; Toonen and Verhage 2007). Munc13, a calciumsensitive presynaptic protein that regulates the priming and probability of release of vesicles, has been shown to influence short-term synaptic plasticity during and following tetanic activation (Brose and Rosenmund 2002; Junge et al. 2004; Beierlein et al. 2007; Shin et al. 2010). It is influenced by many of the pharmacological agents that regulate $\mathrm{PKC}$, and has been proposed as an alternative to PKC as a mediator of PTP and augmentation. Calmodulin and calcium/ calmodulin-dependent kinase II (CaMKII) have also been implicated in PTP (Chapman et al. 1995; Wang and Maler 1998; Fiumara et al. 2007). The abundant Ca/CaMK-sensitive vesicle-associated protein synapsin is also implicated in PTP: The size of vesicle pools and the magnitude of PTP are reduced by $>50 \%$ in synapsin I/II knockout mice (Rosahl et al. 1995). PTP requires phosphorylation of synapsin, and is dependent on cAMP-dependent kinases and CaMKs in snail synapses (Fiumara et al. 2007).

A calcium-dependent increase in the size of miniature synaptic currents following tetanic stimulation may contribute to PTP. At the calyx of Held, tetanic stimulation produces an increase in the size of minis that has a similar time course to PTP (He et al. 2009; Xue and $\mathrm{Wu}$ 2010). In many cases increases in minis size have been associated with increases in the sensitivity of the postsynaptic cell to neurotransmitter. Remarkably, by patching onto the face of the presynaptic terminal and measuring capacitance changes arising from the fusion of individual vesicles, it was shown that calciumdependent increases in the amplitude of minis arise presynaptically from an increase in vesicle size at the calyx of Held. It appears that large and prolonged elevations of presynaptic activity may cause vesicles to fuse with each other before ultimately fusing with presynaptic membranes. Whether presynaptic increases in vesicle size contribute to PTP depends on whether the same pool of vesicles underlies both evoked and spontaneous release or, if that is not the case, whether both pools of vesicles are affected in a similar manner by tetanic stimulation.

An increase in the size of the readily releasable pool of vesicles could also contribute to PTP. At the calyx of Held synapse, a 5-min, $20-\mathrm{Hz}$ stimulation produces a $30 \%$ increase in the size of the RRP (Habets and Borst 2005). Pool size changes have been studied more extensively for $100-\mathrm{Hz}$ stimulation for $4 \mathrm{sec}$, which induces approximately twofold enhancement that is only partially explained by an 
increase in the probability of release (Lee et al. 2008; Fioravante et al. 2011). Tetanic stimulation did not alter the amplitude of the RRP determined with a large presynaptic depolarization, but it did increase the size of a rapidly releasing pool while reducing the size of the slowly releasing pool (Lee et al. 2010), and increased the effective pool size determined by stimulation with high-frequency trains (Lee et al. 2008; Fioravante et al. 2011). Myosin light chain kinase (MLCK) (Lee et al. 2008, 2010) and calcium-dependent PKC (Fioravante et al. 2011) have been implicated in the increases in effective pool size that contribute to PTP.

Multiple molecular mechanisms regulate different aspects of synaptic transmission to produce PTP (Fig. 4E).

\section{FUNCTIONAL ROLES OF PRESYNAPTIC SHORT-TERM PLASTICITY}

Many important functional roles have been described for short-term synaptic plasticity (Abbott and Regehr 2004; Grande and Spain 2005), and several examples illustrate some of these roles. One function of synaptic depression is to mediate sensory adaption, which allows strong responses to novel stimulation and diminished responses to repeated stimuli (Chung et al. 2002). For example, if sensory stimulation activates sensory neurons strongly and continuously, higher-order neurons will only respond strongly to the onset of stimulation if the synapses they receive are strongly depressing (Fig. 5A).

Synaptic depression can also enable sensory systems to respond to percentage changes in intensity rather than absolute changes in intensity. For depressing synapses the steady-state synaptic charge transfer (the product of the firing frequency and the EPSC amplitude) is not strongly affected by firing frequency, because increases in firing frequency are offset by decreases in synaptic strength arising from synaptic depression. However, when the firing frequency increases abruptly, there is a transient increase in charge transfer before steady-state depressing occurs. As shown in Figure 5B for a depressing synapse, comparable transient increases in charge transfer occur when the firing rate is increased from
$1 \mathrm{~Hz}$ to $5 \mathrm{~Hz}$ and from $5 \mathrm{~Hz}$ to $25 \mathrm{~Hz}$, even though the absolute increases in frequency in these two cases are $4 \mathrm{~Hz}$ and $20 \mathrm{~Hz}$, respectively. In this way, a depressing synaptic connection responds transiently to changes in firing rate in a way that encodes percentage changes in firing rate (Abbott et al. 1997).

Short-term synaptic depression can play a crucial role in synaptic computations performed by synapses. This is illustrated by considering input/output curves at mossy fiber-to-granule cell synapses (Rothman et al. 2009). Low-frequency firing of mossy fiber inputs is ineffective at evoking firing of granule cell outputs. As mossy fiber firing rates increase above a critical frequency, there is a roughly linear relation between input and output firing rates, and as input firing rate increases further, the granule cell firing rate plateaus. Synaptic inhibition acts multiplicatively to scale down this input/ output curve, but only if the mossy fiber inputs show short-term depression. In the absence of short-term depression, inhibition affects the input/output curve in a highly nonlinear manner.

Short-term plasticity can also be used to produce directional selectivity, as in the weakly electric fish (Fortune and Rose 2001; Carver et al. 2008). A schematic shows how synapses with differential short-term synaptic plasticity can lead to direction selectivity when two sensory neurons activate a target cell, with one neuron providing a depressing input and the other providing a facilitating input (Fig. 5C). For sustained activation the depressing synapse decreases with time and the facilitating synapse increases and then plateaus. For a stimulus moving from left to right, the depressing synapse is activated first, followed by the facilitating synapse, and the sum of synaptic responses does not exceed the threshold for activating the cell. For a stimulus moving from right to left, the facilitating synapse is activated first, and the summed response exceeds threshold. In this way the spiking in the postsynaptic cell is directionally sensitive.

Short-term synaptic dynamics can also be used to regulate circuit properties, as in the hippocampus, where sustained activation of CA3 pyramidal cells can produce sustained 
W.G. Regehr
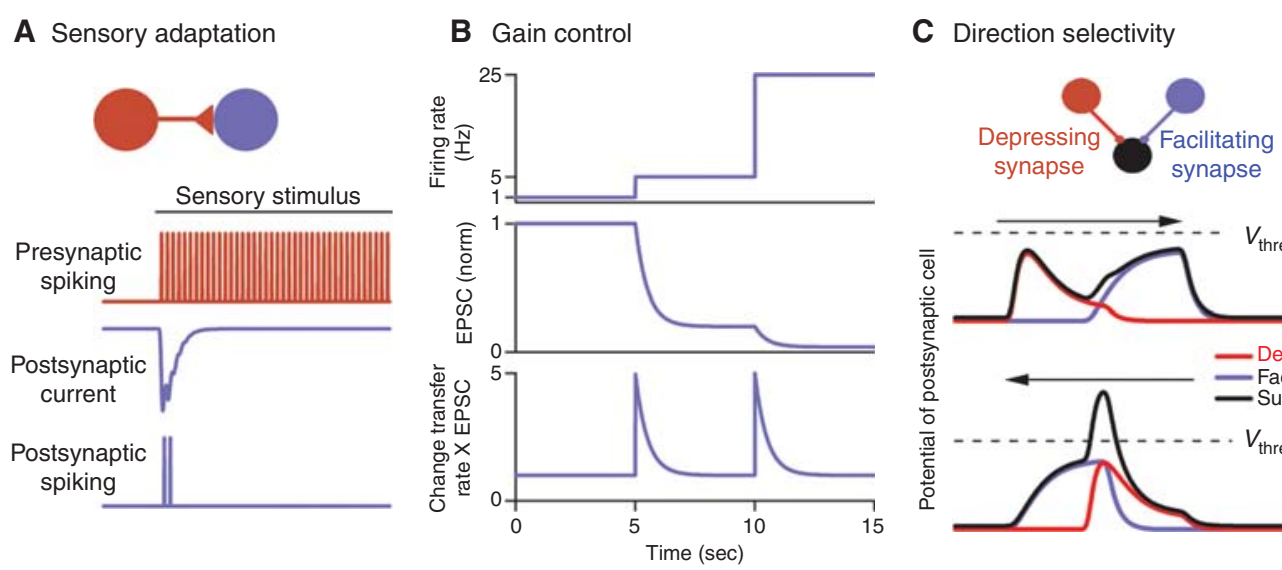

Figure 5. Examples of functional roles of short-term synaptic plasticity. ( $A$ ) If a sensory stimulus activates a neuron (red), as a result of depression the synaptic current in the postsynaptic cell (blue) is only prominent at the onset of stimulus, and as a result the postsynaptic cell only fires at the onset of stimulation. $(B)$ A schematic illustrating the effect of a depressing synapse on the response of postsynaptic cell evoked by changing steady-state firing from $1 \mathrm{~Hz}$ to $5 \mathrm{~Hz}$ to $25 \mathrm{~Hz}$. Because of synaptic depression the synaptic current decreases to a steady-state value during sustained activation, such that the extent of depression offsets the change in firing frequency. As a result the only change in charge transfer occurs when the firing rate is changed and the magnitude of the response is proportional to the percentage change in the firing rate of the presynaptic cell. $(C)$ Direction selectivity can be mediated by a simple circuit of three cells, provided two of the cells are sensory neurons that target a common postsynaptic cell, and the synapses have different synaptic plasticity. In this case the red synapse depresses and the blue synapse facilitates. A sensory stimulus moving from left to right results in a net synaptic current (black) that is the sum of the two synaptic inputs. The potential change does not reach threshold (dashed line) in this case, but if the stimulus moves from right to left, a larger synaptic response is observed and the potential of the postsynaptic cell reaches threshold.

inhibition in dendritic regions and transient inhibition in somatic regions (Pouille and Scanziani 2004). The underlying reason for these different properties is that inhibition onto dendritic and somatic regions is mediated by different types of interneurons, and these neurons are activated by synapses that have different synaptic plasticity, one strongly depressing and the other showing little short-term plasticity. Largely as a result of short-term synaptic plasticity, inhibition shifts from the soma to dendrites during ongoing synaptic activation.

Although most synapses show strong usedependent plasticity, some synapses appear to minimize use-dependent plasticity. For example, at synapses between cerebellar climbing fibers and Purkinje cells, there is prominent presynaptic depression of neurotransmitter release. However, saturation of postsynaptic receptors reduces the extent of changes in synaptic strength, allowing these synapses to provide a more reliable input to Purkinje cells (Wadiche and Jahr 2001; Foster et al. 2002; Blitz et al. 2004). For synapses in the vestibular nucleus, steady-state synaptic strength is independent of the frequency of sustained activation (Bagnall et al. 2008), unlike most synapses, for which depression increases with elevated stimulus frequencies. This lack of plasticity likely reflects the interactions of multiple presynaptic mechanisms, and contributes to the linearity of vestibular reflexes by allowing this synapse to transmit synaptic charge that is linearly related to stimulus frequency.

\section{SUMMARY}

In recent years there has been a growing appreciation of the mechanisms that contribute to short-term plasticity. Quantitative studies are 
now providing sufficient information to determine how different mechanisms combine to ultimately determine synaptic strength. There has also been a steady progression in our understanding of the functions of short-term synaptic plasticity.

\section{REFERENCES}

Abbott LF, Regehr WG. 2004. Synaptic computation. Nature 431: 796-803.

Abbott LF, Varela JA, Sen K, Nelson SB. 1997. Synaptic depression and cortical gain control. Science 275: 220 224.

Adler EM, Augustine GJ, Duffy SN, Charlton MP. 1991. Alien intracellular calcium chelators attenuate neurotransmitter release at the squid giant synapse. J Neurosci 11: 1496-1507.

Alle H, Jonas P, Geiger JR. 2001. PTP and LTP at a hippocampal mossy fiber-interneuron synapse. Proc Natl Acad Sci 98: 14708-14713.

Atluri PP, Regehr WG. 1996. Determinants of the time course of facilitation at the granule cell to Purkinje cell synapse. J Neurosci 16: 5661-5671.

Augustin I, Rosenmund C, Sudhof TC, Brose N. 1999. Munc13-1 is essential for fusion competence of glutamatergic synaptic vesicles. Nature 400: 457-461.

Augustine GJ. 1990. Regulation of transmitter release at the squid giant synapse by presynaptic delayed rectifier potassium current. J Physiol 431: 343-364.

Bagnall MW, McElvain LE, Faulstich M, du Lac S. 2008. Frequency-independent synaptic transmission supports a linear vestibular behavior. Neuron 60: 343-352.

Bain AI, Quastel DM. 1992. Multiplicative and additive $\mathrm{Ca}^{2+}$-dependent components of facilitation at mouse endplates. J Physiol 455: 383-405.

Becherer U, Rettig J. 2006. Vesicle pools, docking, priming, and release. Cell Tissue Res 326: 393-407.

Beierlein M, Fioravante D, Regehr WG. 2007. Differential expression of posttetanic potentiation and retrograde signaling mediate target-dependent short-term synaptic plasticity. Neuron 54: 949-959.

Bertram R, Sherman A, Stanley EF. 1996. Single-domain/ bound calcium hypothesis of transmitter release and facilitation. J Neurophysiol 75: 1919-1931.

Betz WJ. 1970. Depression of transmitter release at the neuromuscular junction of the frog. J Physiol 206: 629644.

Blatow M, Caputi A, Burnashev N, Monyer H, Rozov A. 2003. $\mathrm{Ca}^{2+}$ buffer saturation underlies paired pulse facilitation in calbindin-D28k-containing terminals. Neuron 38: $79-88$.

Blitz DM, Foster KA, Regehr WG. 2004. Short-term synaptic plasticity: A comparison of two synapses. Nat Rev Neurosci 5: 630-640.

Boehm R. 1894. Einige beobachtungen uber die nervenendwirkung des curarin. Arch Exp Pathol Pharmakol 35: $16-22$.
Brager DH, Cai X, Thompson SM. 2003. Activity-dependent activation of presynaptic protein kinase $\mathrm{C}$ mediates post-tetanic potentiation. Nat Neurosci 6: 551-552.

Brain KL, Bennett MR. 1997. Calcium in sympathetic varicosities of mouse vas deferens during facilitation, augmentation and autoinhibition. J Physiol 502: 521-536.

Brenowitz SD, Regehr WG. 2007. Reliability and heterogeneity of calcium signaling at single presynaptic boutons of cerebellar granule cells. J Neurosci 27: 7888-7898.

Brody DL, Yue DT. 2000. Release-independent short-term synaptic depression in cultured hippocampal neurons. $J$ Neurosci 20: 2480-2494.

Brose N, Rosenmund C. 2002. Move over protein kinase C, you've got company: Alternative cellular effectors of diacylglycerol and phorbol esters. J Cell Sci 115: 43994411.

Burnashev N, Rozov A. 2005. Presynaptic $\mathrm{Ca}^{2+}$ dynamics, $\mathrm{Ca}^{2+}$ buffers and synaptic efficacy. Cell Calcium 37: 489495.

Cabin DE, Shimazu K, Murphy D, Cole NB, Gottschalk W, McIlwain KL, Orrison B, Chen A, Ellis CE, Paylor R, et al. 2002. Synaptic vesicle depletion correlates with attenuated synaptic responses to prolonged repetitive stimulation in mice lacking $\alpha$-synuclein. J Neurosci 22: 8797-8807.

Caillard O, Moreno H, Schwaller B, Llano I, Celio MR, Marty A. 2000. Role of the calcium-binding protein parvalbumin in short-term synaptic plasticity. Proc Natl Acad Sci 97: 13372-13377.

Carver S, Roth E, Cowan NJ, Fortune ES. 2008. Synaptic plasticity can produce and enhance direction selectivity. PLoS Comput Biol 4: e32.

Catterall WA, Few AP. 2008. Calcium channel regulation and presynaptic plasticity. Neuron 59: 882-901.

Chapman PF, Frenguelli BG, Smith A, Chen CM, Silva AJ. 1995. The $\alpha-\mathrm{Ca}^{2+} /$ calmodulin kinase II: A bidirectional modulator of presynaptic plasticity. Neuron 14: 591-597.

Charlton MP, Bittner GD. 1978. Facilitation of transmitter release at squid synapses. J Gen Physiol 72: 471-486.

Chen C, Blitz DM, Regehr WG. 2002. Contributions of receptor desensitization and saturation to plasticity at the retinogeniculate synapse. Neuron 33: 779-788.

Chen G, Harata NC, Tsien RW. 2004. Paired-pulse depression of unitary quantal amplitude at single hippocampal synapses. Proc Natl Acad Sci 101: 1063-1068.

Chung S, Li X, Nelson SB. 2002. Short-term depression at thalamocortical synapses contributes to rapid adaptation of cortical sensory responses in vivo. Neuron 34: $437-$ 446.

Cox CL, Denk W, Tank DW, Svoboda K. 2000. Action potentials reliably invade axonal arbors of rat neocortical neurons. Proc Natl Acad Sci 97: 9724-9728.

Crowley JJ, Carter AG, Regehr WG. 2007. Fast vesicle replenishment and rapid recovery from desensitization at a single synaptic release site. J Neurosci 27: 5448-5460.

Cuttle MF, Tsujimoto T, Forsythe ID, Takahashi T. 1998. Facilitation of the presynaptic calcium current at an auditory synapse in rat brainstem. J Physiol 512: 723-729.

de Jong AP, Verhage M. 2009. Presynaptic signal transduction pathways that modulate synaptic transmission. Curr Opin Neurobiol 19: 245-253. 
W.G. Regehr

Deak F, Shin OH, Tang J, Hanson P, Ubach J, Jahn R, Rizo J, Kavalali ET, Sudhof TC. 2006. Rabphilin regulates SNARE-dependent re-priming of synaptic vesicles for fusion. EMBO J 25: 2856-2866.

Debanne D, Guerineau NC, Gahwiler BH, Thompson SM 1996. Paired-pulse facilitation and depression at unitary synapses in rat hippocampus: Quantal fluctuation affects subsequent release. J Physiol 491: 163-176.

del Castillo J, Katz B. 1954. Statistical factors involved in neuromuscular facilitation and depression. J Physiol 124: $574-585$.

Delaney KR, Tank DW. 1994. A quantitative measurement of the dependence of short-term synaptic enhancement on presynaptic residual calcium. J Neurosci 14: 5885-5902.

Delaney KR, Zucker RS, Tank DW. 1989. Calcium in motor nerve terminals associated with posttetanic potentiation. J Neurosci 9: 3558-3567.

Dittman JS, Regehr WG. 1998. Calcium dependence and recovery kinetics of presynaptic depression at the climbing fiber to Purkinje cell synapse. J Neurosci 18: 61476162.

Dittman JS, Kreitzer AC, Regehr WG. 2000. Interplay between facilitation, depression, and residual calcium at three presynaptic terminals. J Neurosci 20: 1374-1385.

Eccles JC, O'Connor WJ. 1941. Abortive impulses at the neuro-muscular junction. J Physiol 100: 318-328.

Eliot LS, Kandel ER, Hawkins RD. 1994. Modulation of spontaneous transmitter release during depression and posttetanic potentiation of Aplysia sensory-motor neuron synapses isolated in culture. J Neurosci 14: $3280-$ 3292.

Elmqvist D, Quastel DM. 1965. A quantitative study of endplate potentials in isolated human muscle. J Physiol 178: 505-529.

Felmy F, Neher E, Schneggenburger R. 2003. Probing the intracellular calcium sensitivity of transmitter release during synaptic facilitation. Neuron 37: 801-811.

Feng TP. 1941. Studies on the neuromuscular junction XXVI. The changes of the end-plate potential during and after prolonged stimulation. Chin J Physiol 16: 341372.

Fioravante D, Regehr WG. 2011. Short-term forms of presynaptic plasticity. Curr Opin Neurobiol 21: 269-274.

Fioravante D, Chu Y, Myoga MH, Leitges M, Regehr WG. 2011. Calcium-dependent isoforms of protein kinase $C$ mediate posttetanic potentiation at the calyx of Held. Neuron 70: 1005-1019.

Fiumara F, Milanese C, Corradi A, Giovedi S, Leitinger G, Menegon A, Montarolo PG, Benfenati F, Ghirardi M. 2007. Phosphorylation of synapsin domain $A$ is required for post-tetanic potentiation. J Cell Sci 120: 3228-3237.

Fogelson AL, Zucker RS. 1985. Presynaptic calcium diffusion from various arrays of single channels. Implications for transmitter release and synaptic facilitation. Biophys J 48: 1003-1017.

Forsythe ID, Tsujimoto T, Barnes-Davies M, Cuttle MF, Takahashi T. 1998. Inactivation of presynaptic calcium current contributes to synaptic depression at a fast central synapse. Neuron 20: 797-807.

Fortune ES, Rose GJ. 2001. Short-term synaptic plasticity as a temporal filter. Trends Neurosci 24: 381-385.
Foster KA, Kreitzer AC, Regehr WG. 2002. Interaction of postsynaptic receptor saturation with presynaptic mechanisms produces a reliable synapse. Neuron 36: 11151126.

Foster KA, Crowley JJ, Regehr WG. 2005. The influence of multivesicular release and postsynaptic receptor saturation on transmission at granule cell to Purkinje cell synapses. J Neurosci 25: 11655-11665.

Francotte P, de Tullio P, Fraikin P, Counerotte S, Goffin E, Pirotte B. 2006. In search of novel AMPA potentiators. Recent Pat CNS Drug Discov 1: 239-246.

Furukawa T, Hayashida Y, Matsuura S. 1978. Quantal analysis of the size of excitatory post-synaptic potentials at synapses between hair cells and afferent nerve fibres in goldfish. J Physiol 276: 211-226.

Garcia-Chacon LE, Nguyen KT, David G, Barrett EF. 2006. Extrusion of $\mathrm{Ca}^{2+}$ from mouse motor terminal mitochondria via a $\mathrm{Na}^{+}-\mathrm{Ca}^{2+}$ exchanger increases post-tetanic evoked release. J Physiol 574: 663-675.

Geiger JR, Jonas P. 2000. Dynamic control of presynaptic $\mathrm{Ca}^{2+}$ inflow by fast-inactivating $\mathrm{K}^{+}$channels in hippocampal mossy fiber boutons. Neuron 28: 927-939.

Gitler D, Cheng Q, Greengard P, Augustine GJ. 2008. Synapsin IIa controls the reserve pool of glutamatergic synaptic vesicles. J Neurosci 28: 10835-10843.

Grande LA, Spain WJ. 2005. Synaptic depression as a timing device. Physiology (Bethesda) 20: 201-210.

Griffith WH. 1990. Voltage-clamp analysis of posttetanic potentiation of the mossy fiber to CA3 synapse in hippocampus. J Neurophysiol 63: 491-501.

Habets RL, Borst JG. 2005. Post-tetanic potentiation in the rat calyx of Held synapse. J Physiol 564: 173-187.

Habets RL, Borst JG. 2006. An increase in calcium influx contributes to post-tetanic potentiation at the rat calyx of Held synapse. J Neurophysiol 96: 2868-2876.

Hallermann S, Fejtova A, Schmidt H, Weyhersmuller A, Silver RA, Gundelfinger ED, Eilers J. 2010. Bassoon speeds vesicle reloading at a central excitatory synapse. Neuron 68: 710-723.

He L, Xue L, Xu J, McNeil BD, Bai L, Melicoff E, Adachi R, Wu LG. 2009. Compound vesicle fusion increases quantal size and potentiates synaptic transmission. Nature 459: 93-97.

Hosoi N, Sakaba T, Neher E. 2007. Quantitative analysis of calcium-dependent vesicle recruitment and its functional role at the calyx of Held synapse. J Neurosci 27: 1428614298.

Hosoi N, Holt M, Sakaba T. 2009. Calcium dependence of exo- and endocytotic coupling at a glutamatergic synapse. Neuron 63: 216-229.

Hughes JR. 1958. Post-tetanic potentiation. Physiol Rev 38: 91-113.

Inchauspe CG, Martini FJ, Forsythe ID, Uchitel OD. 2004. Functional compensation of $\mathrm{P} / \mathrm{Q}$ by $\mathrm{N}$-type channels blocks short-term plasticity at the calyx of Held presynaptic terminal. J Neurosci 24: 10379-10383.

Ishikawa T, Kaneko M, Shin HS, Takahashi T. 2005. Presynaptic N-type and P/Q-type $\mathrm{Ca}^{2+}$ channels mediating synaptic transmission at the calyx of Held of mice. J Physiol 568: 199-209. 
Jahn R, Lang T, Sudhof TC. 2003. Membrane fusion. Cell 112: 519-533.

Junge HJ, Rhee JS, Jahn O, Varoqueaux F, Spiess J, Waxham MN, Rosenmund C, Brose N. 2004. Calmodulin and Munc13 form a Ca ${ }^{2+}$ sensor/effector complex that controls short-term synaptic plasticity. Cell 118: 389-401.

Katz B, Miledi R. 1968. The role of calcium in neuromuscular facilitation. J Physiol 195: 481-492.

Korn H, Sur C, Stephane C, Legendre P, Faber D. 1994. The one-vesicle hypothesis and multivesicular release. In Molecular and cellular mechanisms of neurotransmitter release (ed. Stjarne L), pp. 301-322. Lippincott Williams and Wilkins, New York.

Korogod N, Lou X, Schneggenburger R. 2005. Presynaptic $\mathrm{Ca}^{2+}$ requirements and developmental regulation of posttetanic potentiation at the calyx of Held. J Neurosci 25: 5127-5137.

Korogod N, Lou X, Schneggenburger R. 2007. Posttetanic potentiation critically depends on an enhanced $\mathrm{Ca}^{2+}$ sensitivity of vesicle fusion mediated by presynaptic PKC. Proc Natl Acad Sci 104: 15923-15928.

Kraushaar U, Jonas P. 2000. Efficacy and stability of quantal GABA release at a hippocampal interneuron-principal neuron synapse. J Neurosci 20: 5594-5607.

Kreitzer AC, Regehr WG. 2001. Retrograde inhibition of presynaptic calcium influx by endogenous cannabinoids at excitatory synapses onto Purkinje cells. Neuron 29: 717-727.

Kusano K, Landau EM. 1975. Depression and recovery of transmission at the squid giant synapse. J Physiol 245: $13-32$.

Lautermilch NJ, Few AP, Scheuer T, Catterall WA. 2005. Modulation of $\mathrm{Ca}_{\mathrm{V}} 2.1$ channels by the neuronal calcium-binding protein visinin-like protein-2. J Neurosci 25: 7062-7070.

Lee A, Wong ST, Gallagher D, Li B, Storm DR, Scheuer T, Catterall WA. 1999. $\mathrm{Ca}^{2+} /$ calmodulin binds to and modulates P/Q-type calcium channels. Nature 399: 155-159.

Lee SH, Schwaller B, Neher E. 2000. Kinetics of $\mathrm{Ca}^{2+}$ binding to parvalbumin in bovine chromaffin cells: Implications for $\left[\mathrm{Ca}^{2+}\right]$ transients of neuronal dendrites. J Physiol 525: 419-432.

Lee A, Westenbroek RE, Haeseleer F, Palczewski K, Scheuer T, Catterall WA. 2002. Differential modulation of $\mathrm{Ca}_{\mathrm{v}} 2.1$ channels by calmodulin and $\mathrm{Ca}^{2+}$-binding protein 1 . Nat Neurosci 5: 210-217.

Lee D, Lee KH, Ho WK, Lee SH. 2007. Target cell-specific involvement of presynaptic mitochondria in post-tetanic potentiation at hippocampal mossy fiber synapses. J Neurosci 27: 13603-13613.

Lee JS, Kim MH, Ho WK, Lee SH. 2008. Presynaptic release probability and readily releasable pool size are regulated by two independent mechanisms during posttetanic potentiation at the calyx of Held synapse. J Neurosci 28: $7945-7953$.

Lee JS, Ho WK, Lee SH. 2010. Post-tetanic increase in the fast-releasing synaptic vesicle pool at the expense of the slowly releasing pool. J Gen Physiol 136: 259-272.

Liley AW, North KA. 1953. An electrical investigation of effects of repetitive stimulation on mammalian neuromuscular junction. J Neurophysiol 16: 509-527.
Magleby KL. 1987. Short-term changes in synaptic efficacy. In Synaptic function (ed. Edelman GM, et al.), pp. 21-56. Wiley, New York.

Magleby KL, Zengel JE. 1975. A quantitative description of tetanic and post-tetanic potentiation of transmitter release at the frog neuromuscular junction. J Physiol 245: 183-208.

Martin AR, Pilar G. 1964. Presynaptic and post-synaptic events during post-tetanic potentiation and facilitation in the avian ciliary ganglion. J Physiol 175: 17-30.

Matveev V, Zucker RS, Sherman A. 2004. Facilitation through buffer saturation: Constraints on endogenous buffering properties. Biophys J 86: 2691-2709.

Mochida S, Few AP, Scheuer T, Catterall WA. 2008. Regulation of presynaptic $\mathrm{Ca}_{2} 2.1$ channels by $\mathrm{Ca}^{2+}$ sensor proteins mediates short-term synaptic plasticity. Neuron $\mathbf{5 7}$ 210-216.

Mulkey RM, Zucker RS. 1992. Posttetanic potentiation at the crayfish neuromuscular junction is dependent on both intracellular calcium and sodium ion accumulation. J Neurosci 12: 4327-4336.

Muller M, Felmy F, Schwaller B, Schneggenburger R. 2007. Parvalbumin is a mobile presynaptic $\mathrm{Ca}^{2+}$ buffer in the calyx of Held that accelerates the decay of $\mathrm{Ca}^{2+}$ and shortterm facilitation. J Neurosci 27: 2261-2271.

Munoz-Cuevas J, Vara H, Colino A. 2004. Characterization of release-independent short-term depression in the juvenile rat hippocampus. J Physiol 558: 527-548.

Neher E. 1998. Usefulness and limitations of linear approximations to the understanding of $\mathrm{Ca}^{2+}$ signals. Cell Calcium 24: 345-357.

Neher E, Augustine GJ. 1992. Calcium gradients and buffers in bovine chromaffin cells. J Physiol 450: 273-301.

Neher E, Sakaba T. 2001. Estimating transmitter release rates from postsynaptic current fluctuations. J Neurosci 21 9638-9654.

Neher E, Sakaba T. 2008. Multiple roles of calcium ions in the regulation of neurotransmitter release. Neuron 59: 861-872.

Nili U, de Wit H, Gulyas-Kovacs A, Toonen RF, Sorensen JB, Verhage M, Ashery U. 2006. Munc18-1 phosphorylation by protein kinase $\mathrm{C}$ potentiates vesicle pool replenishment in bovine chromaffin cells. Neuroscience 143: 487-500.

Pan B, Zucker RS. 2009. A general model of synaptic transmission and short-term plasticity. Neuron 62: 539-554.

Peterson BZ, DeMaria CD, Adelman JP, Yue DT. 1999. Calmodulin is the $\mathrm{Ca}^{2+}$ sensor for $\mathrm{Ca}^{2+}$-dependent inactivation of L-type calcium channels. Neuron 22: 549-558.

Pouille F, Scanziani M. 2004. Routing of spike series by dynamic circuits in the hippocampus. Nature 429: 717-723.

Prakriya M, Mennerick S. 2000. Selective depression of lowrelease probability excitatory synapses by sodium channel blockers. Neuron 26: 671-682.

Ran I, Quastel DM, Mathers DA, Puil E. 2009. Fluctuation analysis of tetanic rundown (short-term depression) at a corticothalamic synapse. Biophys J 96: 2505-2531.

Redman S. 1990. Quantal analysis of synaptic potentials in neurons of the central nervous system. Physiol Rev 70: $165-198$. 
W.G. Regehr

Regehr WG. 1997. Interplay between sodium and calcium dynamics in granule cell presynaptic terminals. Biophys $J$ 73: $2476-2488$.

Regehr WG, Delaney KR, Tank DW. 1994. The role of presynaptic calcium in short-term enhancement at the hippocampal mossy fiber synapse. J Neurosci 14: 523-537.

Reymann KG, Brodemann R, Kase H, Matthies H. 1988a Inhibitors of calmodulin and protein kinase $\mathrm{C}$ block different phases of hippocampal long-term potentiation. Brain Res 461: 388-392.

Reymann KG, Frey U, Jork R, Matthies H. 1988b. Polymyxin $\mathrm{B}$, an inhibitor of protein kinase $\mathrm{C}$, prevents the maintenance of synaptic long-term potentiation in hippocampal CA1 neurons. Brain Res 440: 305-314.

Rizzoli SO, Betz WJ. 2005. Synaptic vesicle pools. Nat Rev Neurosci 6: 57-69.

Roberts WM. 1993. Spatial calcium buffering in saccular hair cells. Nature 363: 74-76.

Rosahl TW, Spillane D, Missler M, Herz J, Selig DK, Wolff JR, Hammer RE, Malenka RC, Sudhof TC. 1995. Essential functions of synapsins I and II in synaptic vesicle regulation. Nature 375: 488-493.

Rosenmund C, Stevens CF. 1996. Definition of the readily releasable pool of vesicles at hippocampal synapses. $\mathrm{Neu}$ ron 16: 1197-1207.

Rothman JS, Cathala L, Steuber V, Silver RA. 2009. Synaptic depression enables neuronal gain control. Nature 457: 1015-1018.

Rozov A, Burnashev N, Sakmann B, Neher E. 2001. Transmitter release modulation by intracellular $\mathrm{Ca}^{2+}$ buffers in facilitating and depressing nerve terminals of pyramidal cells in layer $2 / 3$ of the rat neocortex indicates a target cell-specific difference in presynaptic calcium dynamics. $J$ Physiol 531: 807-826.

Sabatini BL, Regehr WG. 1997. Control of neurotransmitter release by presynaptic waveform at the granule cell to Purkinje cell synapse. J Neurosci 17: 3425-3435.

Sakaba T. 2008. Two $\mathrm{Ca}^{2+}$-dependent steps controlling synaptic vesicle fusion and replenishment at the cerebellar basket cell terminal. Neuron 57: 406-419.

Sakaba T, Neher E. 2001. Calmodulin mediates rapid recruitment of fast-releasing synaptic vesicles at a calyxtype synapse. Neuron 32: 1119-1131.

Sakaba T, Neher E. 2003. Direct modulation of synaptic vesicle priming by $\mathrm{GABA}_{\mathrm{B}}$ receptor activation at a glutamatergic synapse. Nature 424: 775-778.

Satzler K, Sohl LF, Bollmann JH, Borst JG, Frotscher M, Sakmann B, Lubke JH. 2002. Three-dimensional reconstruction of a calyx of Held and its postsynaptic principal neuron in the medial nucleus of the trapezoid body. $J$ Neurosci 22: 10567-10579.

Saviane C, Silver RA. 2006. Fast vesicle reloading and a large pool sustain high bandwidth transmission at a central synapse. Nature 439: 983-987.

Scheuss V, Schneggenburger R, Neher E. 2002. Separation of presynaptic and postsynaptic contributions to depression by covariance analysis of successive EPSCs at the calyx of Held synapse. J Neurosci 22: 728-739.

Schiff JM. 1858. Lehrbuch der physiologie des menschen: I. Muskel- und nervenphysiologie. Schauenburg, Lahr, Germany.
Schikorski T, Stevens CF. 1999. Quantitative fine-structural analysis of olfactory cortical synapses. Proc Natl Acad Sci 96: 4107-4112.

Schneggenburger R, Neher E. 2005. Presynaptic calcium and control of vesicle fusion. Curr Opin Neurobiol 15: 266-274.

Schneggenburger R, Sakaba T, Neher E. 2002. Vesicle pools and short-term synaptic depression: Lessons from a large synapse. Trends Neurosci 25: 206-212.

Schweizer FE, Ryan TA. 2006. The synaptic vesicle: Cycle of exocytosis and endocytosis. Curr Opin Neurobiol 16: $298-304$.

Shin OH, Lu J, Rhee JS, Tomchick DR, Pang ZP, Wojcik SM, Camacho-Perez M, Brose N, Machius M, Rizo J, et al. 2010. Munc13 C2B domain is an activity-dependent $\mathrm{Ca}^{2+}$ regulator of synaptic exocytosis. Nat Struct Mol Biol 17: 280-288.

Simon SM, Llinas RR. 1985. Compartmentalization of the submembrane calcium activity during calcium influx and its significance in transmitter release. Biophys J 48: 485-498.

Stanley EF. 1984. The action of cholinergic agonists on the squid stellate ganglion giant synapse. J Neurosci 4: 1904-1911.

Stevens CF, Wesseling JF. 1998. Activity-dependent modulation of the rate at which synaptic vesicles become available to undergo exocytosis. Neuron 21: 415-424.

Stevens CF, Wesseling JF. 1999. Augmentation is a potentiation of the exocytotic process. Neuron 22: 139-146.

Sudhof TC, Rothman JE. 2009. Membrane fusion: Grappling with SNARE and SM proteins. Science 323: 474477.

Sullivan JM. 2007. A simple depletion model of the readily releasable pool of synaptic vesicles cannot account for paired-pulse depression. J Neurophysiol 97: 948-950.

Tang Y, Zucker RS. 1997. Mitochondrial involvement in post-tetanic potentiation of synaptic transmission. $\mathrm{Neu}$ ron 18: 483-491.

Tank DW, Regehr WG, Delaney KR. 1995. A quantitative analysis of presynaptic calcium dynamics that contribute to short-term enhancement. J Neurosci 15: 7940-7952.

Thomson AM, Bannister AP. 1999. Release-independent depression at pyramidal inputs onto specific cell targets: Dual recordings in slices of rat cortex. $J$ Physiol 519: 57-70.

Thomson AM, Deuchars J, West DC. 1993. Large, deep layer pyramid-pyramid single axon EPSPs in slices of rat motor cortex display paired pulse and frequency-dependent depression, mediated presynaptically and self-facilitation, mediated postsynaptically. J Neurophysiol 70: 2354-2369.

Toonen RF, Verhage M. 2007. Munc18-1 in secretion: Lonely Munc joins SNARE team and takes control. Trends Neurosci 30: 564-572.

Toonen RF, Wierda K, Sons MS, de Wit H, Cornelisse LN, Brussaard A, Plomp JJ, Verhage M. 2006. Munc18-1 expression levels control synapse recovery by regulating readily releasable pool size. Proc Natl Acad Sci 103: 18332-18337. 
Trussell LO, Zhang S, Raman IM. 1993. Desensitization of AMPA receptors upon multiquantal neurotransmitter release. Neuron 10: 1185-1196.

Varela JA, Sen K, Gibson J, Fost J, Abbott LF, Nelson SB. 1997. A quantitative description of short-term plasticity at excitatory synapses in layer $2 / 3$ of rat primary visual cortex. J Neurosci 17: 7926-7940.

von Gersdorff H, Borst JG. 2002. Short-term plasticity at the calyx of Held. Nat Rev Neurosci 3: 53-64.

Wadel K, Neher E, Sakaba T. 2007. The coupling between synaptic vesicles and $\mathrm{Ca}^{2+}$ channels determines fast neurotransmitter release. Neuron 53: 563-575.

Wadiche JI, Jahr CE. 2001. Multivesicular release at climbing fiber-Purkinje cell synapses. Neuron 32: 301-313.

Waldeck RF, Pereda A, Faber DS. 2000. Properties and plasticity of paired-pulse depression at a central synapse. $J$ Neurosci 20: 5312-5320.

Wang LY, Kaczmarek LK. 1998. High-frequency firing helps replenish the readily releasable pool of synaptic vesicles. Nature 394: 384-388.

Wang D, Maler L. 1998. Differential roles of $\mathrm{Ca}^{2+} /$ calmodulin-dependent kinases in posttetanic potentiation at input selective glutamatergic pathways. Proc Natl Acad Sci 95: 7133-7138.

Wu LG, Borst JG. 1999. The reduced release probability of releasable vesicles during recovery from short-term synaptic depression. Neuron 23: 821-832.
Xu J, Wu LG. 2005. The decrease in the presynaptic calcium current is a major cause of short-term depression at a calyx-type synapse. Neuron 46: 633-645.

Xue L, Wu LG. 2010. Post-tetanic potentiation is caused by two signalling mechanisms affecting quantal size and quantal content. J Physiol 588: 4987-4994.

Xu-Friedman MA, Regehr WG. 2004. Structural contributions to short-term synaptic plasticity. Physiol Rev 84: 69-85.

Yamada WM, Zucker RS. 1992. Time course of transmitter release calculated from simulations of a calcium diffusion model. Biophys J 61: 671-682.

Yang H, Xu-Friedman MA. 2008. Relative roles of different mechanisms of depression at the mouse endbulb of Held. J Neurophysiol 99: 2510-2521.

Zhong N, Beaumont V, Zucker RS. 2001. Roles for mitochondrial and reverse mode $\mathrm{Na}^{+} / \mathrm{Ca}^{2+}$ exchange and the plasmalemma $\mathrm{Ca}^{2+}$ ATPase in post-tetanic potentiation at crayfish neuromuscular junctions. J Neurosci 21: 9598-9607.

Zucker RS, Lara-Estrella LO. 1983. Post-tetanic decay of evoked and spontaneous transmitter release and a residual-calcium model of synaptic facilitation at crayfish neuromuscular junctions. J Gen Physiol 81: 355-372.

Zucker RS, Regehr WG. 2002. Short-term synaptic plasticity. Annu Rev Physiol 64: 355-405. 


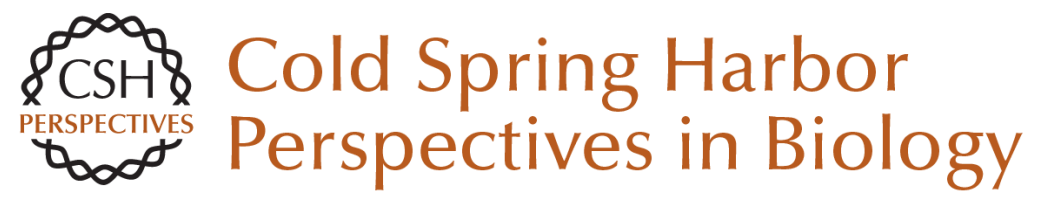

\section{Short-Term Presynaptic Plasticity}

Wade G. Regehr

Cold Spring Harb Perspect Biol 2012; doi: 10.1101/cshperspect.a005702

Subject Collection The Synapse

Studying Signal Transduction in Single Dendritic

Spines

Ryohei Yasuda

Synaptic Vesicle Pools and Dynamics AbdulRasheed A. Alabi and Richard W. Tsien

Synapses and Memory Storage

Mark Mayford, Steven A. Siegelbaum and Eric R. Kandel

Synapses and Alzheimer's Disease

Morgan Sheng, Bernardo L. Sabatini and Thomas C. Südhof

Synaptic Cell Adhesion

Markus Missler, Thomas C. Südhof and Thomas Biederer

Synaptic Dysfunction in Neurodevelopmental

Disorders Associated with Autism and Intellectual

Disabilities

Huda Y. Zoghbi and Mark F. Bear

The Postsynaptic Organization of Synapses Morgan Sheng and Eunjoon Kim

Presynaptic LTP and LTD of Excitatory and Inhibitory Synapses

Pablo E. Castillo
Synaptic Vesicle Endocytosis

Yasunori Saheki and Pietro De Camilli

Short-Term Presynaptic Plasticity

Wade G. Regehr

NMDA Receptor-Dependent Long-Term

Potentiation and Long-Term Depression

(LTP/LTD)

Christian Lüscher and Robert C. Malenka

Ultrastructure of Synapses in the Mammalian

Brain

Kristen M. Harris and Richard J. Weinberg

Calcium Signaling in Dendritic Spines

Michael J. Higley and Bernardo L. Sabatini

Synaptic Neurotransmitter-Gated Receptors

Trevor G. Smart and Pierre Paoletti

Synaptic Vesicle Exocytosis

Thomas C. Südhof and Josep Rizo

Vesicular and Plasma Membrane Transporters for

Neurotransmitters

Randy D. Blakely and Robert H. Edwards

For additional articles in this collection, see http://cshperspectives.cshlp.org/cgi/collection/

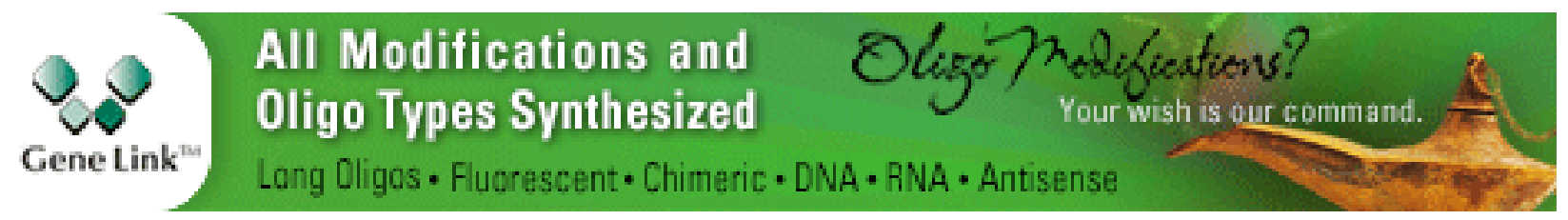

Copyright @ 2012 Cold Spring Harbor Laboratory Press; all rights reserved 